\title{
The Costa Rican business sector's concepts of the transfer of German dual training
}

Concepciones del sector empresarial costarricense sobre la transferencia del modelo de formación dual alemán

\section{Volumen 21, Número 2 \\ Mayo - Agosto \\ pp. 1-30}

Daniel Láscarez-Smith Johannes K. Schmees

Citar este documento según modelo APA

Láscarez-Smith, Daniel., y Schmees, Johannes K. (2021). The Costa Rican business sector's concepts of the transfer of German dual training. Revista Actualidades Investigativas en Educación, 21(2), 1-30. Doi. 10.15517/aie.v21i2.46792 


\title{
The Costa Rican business sector's concepts of the transfer of German dual training \\ Concepciones del sector empresarial costarricense sobre la transferencia del modelo de formación dual alemán
}

\author{
Daniel Láscarez-Smith ${ }^{1}$ \\ Johannes K. Schmees ${ }^{2}$
}

\begin{abstract}
This article analyzes the tripartite social dialogue of an inter-institutional commission in Costa Rica, which took place from February 27 to September 1, 2017. During this time the Costa Rican state the business sector and unions discussed ways to implement dual vocational education and training (VET) in Costa Rica, using the German model as a reference. Here, the focus is on the business sector's concepts regarding if and how the German dual VET model should be transferred to Costa Rica. the findings are based on two interviews with Costa Rican business representatives and the observation of dialogue table meetings with representatives from the state, the business sector and unions. Based on the premise that discourses express and influence social practices, it is analyzed how the structure of the business sector's arguments relate to Toulmin's model of argumentation. It is concluded that from the Costa Rican business sector's point of view, the policy of dual education in VET is essential to gain economic strength in a global market. However, for these business groups, the model must be "tropicalized" in a way that redefines some of the bases of the German reference model, such as union participation, distribution of training costs as well as the legal status of the apprentice. Therefore, it is concluded that the discussion on the dual model of VET was used as a window of opportunity to promote reforms that would favor the business sector.
\end{abstract}

Keywords: youth employment, technical education, educational policy, dual training, policy transfer

Resumen: En el presente artículo se analiza el diálogo social tripartito de una comisión interinstitucional en Costa Rica, el cual se llevó a cabo desde el 27 de febrero hasta el 1 de septiembre de 2017. Durante este tiempo, el estado representado por el Instituto Nacional de Aprendizaje (INA), el Ministerio de Trabajo (MTSS) y el Ministerio de Educación (MEP), el sector empresarial y los sindicatos discutieron sobre la manera de implementar la educación dual en Costa Rica, utilizando como referencia el modelo alemán. Por lo tanto, nos centramos en las concepciones del sector empresarial del por qué y cómo el modelo de formación dual alemán debería ser transferido a Costa Rica. Para el análisis cualitativo se realizaron dos entrevistas con los representantes de los empresarios costarricenses y se observaron sesiones de la mesa de diálogo. Desde el punto de vista de que los discursos expresan e influyen en las prácticas sociales, analizamos la estructura de los argumentos empresariales, según el modelo de Toulmin, el cual ofrece una lógica argumentativa para realizar las inferencias. Concluimos que la implementación de una política educativa dual desde el punto de vista del sector empresarial es esencial para que Costa Rica gane fuerza económica en un mercado global. Sin embargo, el modelo de educación dual debería "tropicalizarse", de manera que se redefinan algunas de las bases del modelo de referencia alemán, como la limitada participación sindical, la distribución y reducción de costos de la formación y el estatus legal del aprendiz. Por lo tanto, se concluye que la discusión sobre el modelo dual de Educación y Formación Técnica Profesional (EFTP), se utilizó como una ventana de oportunidad para impulsar reformas que favorecieran al sector empresarial.

Palabras clave: empleo de jóvenes, educación técnica, política educativa, educación dual, transferencia política

\footnotetext{
${ }^{1}$ Lecturer and doctoral candidate at the Osnabrück University, Osnabrück, Germany. Master in Economic Planning, National University, Costa Rica. Dirección electrónica: dlascarezsmi@uniosnabrueck.de Orcid https://orcid.org/0000-0001-7116-0552
}

2 Postdoctoral research fellow at the Osnabrück University, Osnabrück, Germany. Dr.phil. Osnabrück University, Germany.Dirección electrónica: johannes.schmees@uni-osnabrueck.de Orcid: https://orcid.org/0000-0002-0983-8155

Artículo recibido: 30 de noviembre, 2020

Enviado a corrección: 25 de febrero, 2021

Aprobado: 19 de abril, 2021

Los contenidos de este artículo están bajo una licencia Creative Commons 


\section{Introduction}

Since the 2000s, the Costa Rican labor market has been characterized by a weakened capacity to absorb the young population in quality jobs (INEC, 2020a; 2020b): The open unemployment rate for the last quarter of 2019 among young people aged 15 to 24 was $24 \%$ the long-term trend provides a more pessimistic outlook, as the unemployment rate has increased since the beginning of 2000 (Instituto de Estadísticas y Censos [INEC], 2020a). To address this problem, the Costa Rican government proposed a twofold approach in 2016: first, more employment-related and educational opportunities should be extended to professionals without a college education; second, the education system itself should respond more adequately to the demands of the Costa Rican business sector. As Central European countries with a dual vocational education and training (VET) system such as Austria, Denmark, Germany and Switzerland are widely known for their low youth unemployment rates due to the better fit between professionals and the business sector (Lassnigg, 2015) ${ }^{3}$, such systems were conceived of as models for the Costa Rican approach.

As Láscarez (2017, pp. 43-51) indicates, the origins of the discussion on the possibility of implementing dual education in Costa Rica can be traced back to the late 70's, but it was not until the early 90's that this possibility was formally discussed. Between 1991 and 2000, several pilot projects in dual education were implemented (Mittmann, 2001), and in 1998 the National Integrated System of Technical Education for Competitiveness (SINETEC ${ }^{4}$ ) was created, which laid the foundations for the relationship between companies and VET institutions. Since 2010, several bills have been proposed to implement a dual training system in Costa Rica. One of the most important characteristics of this policy process was the participation of international organizations like the International Labour Organization (ILO), which, following Recommendation No. 195 on human resources development (ILO, 2004), supported the Costa Rican Minister of Education's request for a tripartite social dialogue on the implementation of dual education in Costa Rica (Ministerio de Educación Pública [MEP], 2017)5 ${ }^{5}$ German institutions and organizations also participated, including the Federal Ministry of Education and

\footnotetext{
${ }^{3}$ However, Lassnigg (2015) discusses the export of the dual system of Austria, Germany and Switzerland as "myth" and therefore from a rather critical perspective.

${ }^{4}$ Sistema Integrado Nacional de Educación Técnica para la Competitividad

${ }^{5}$ It is important to note that before the establishment of the tripartite dialogue table, in 2015 , thanks to the cooperation between the governments of Germany and Costa Rica and with the support of Osnabrück University, Germany, and the Universidad Técnica Nacional, Costa Rica, a pilot plan was designed for dual training in the career of automotive mechanics. This pilot plan is part of the efforts to transfer characteristics of the German model in four Costa Rican technical secondary schools. A detailed description of the history of this process can be found in Láscarez (2017) and Láscarez \& Baumann (2020).
} 
Research (BMBF), the Federal Institute for Vocational Education and Training (BIBB), the German Trade Union Confederation, the Association of German Chambers of Industry and Commerce and Osnabrück University, due to its relationship of scientific exchange on professional training with Costa Rica.

The participation of German institutions was underpinned by the decision of the Costa Rican government authorities to take the German dual vocational training system as a reference, despite the fact that the ILO and other entities presented various model options. A detailed analysis, however, on why the German model was selected is beyond the scope of this article. Here, it can be stated in line with Gessler, Fuchs \& Pilz (2019, pp. 4, 8-9) that the worldwide popularity of the German dual system as well as the institutional capacity to export projects contribute to a dynamic in which local actors recognize the German system as one that could respond to the labor market and integrate youth into society and employment. Additionally, Germany is the largest global donor for the promotion of dual training systems, and the growing multinational demand for German experts has generated a pattern in which this system is exported globally, reflected by the multiplicity of German actors and institutions in the international context (Heller, Grunau \& Duscha, 2015, p. 7).

In February 2016, at the request of the President of Costa Rica, the BMBF visited Costa Rica to initiate bilateral cooperation promoting dual training in Costa Rica ${ }^{6}$. The cooperation focused on two aspects that were, from the German perspective, most relevant for the policy transfer's success: tripartite dialogue and legislation defining the relations between different actors within the VET system. Apart from these two priorities, five additional aspects were mentioned by the BMBF: (1) cooperation between political actors and social partners-through e.g. examination boards and training standards, (2) the characteristics of learning in the work process, (3) the creation and social acceptance of training standards, (4) certificates within the national qualifications framework, the importance of training staff (instructors and teachers) and (5) the importance of institutionalized research and counseling.

In early 2017, the Costa Rican government then organized a national tripartite social dialogue to reach a national consensus for drafting a dual training law for Costa Rica (MEP, 2017). This idea was derived from the organizational model of the dual VET system in Germany, based on the tripartite social dialogue between the state, the business sector and unions on the federal, the federated state and the regional level. In addition, the Costa Rican

\footnotetext{
${ }^{6}$ See information about GoVet in this link https://www.bibb.de/govet/de/28964.php, accessed on April 27, 2021
} 
dialogue table was moderated by the ILO, which guides dissuasive actions around tripartite social dialogue schemes. From the beginning of the roundtable, it was assumed that social dialogue itself as well as the governance structure of the dual training should be of a tripartite nature. However, the dialogue lasted only seven months, from February to September 2017, without accountable results. The dialogue's breakdown was due to the change of government, but it is primarily attributable to major differences between unions and employers regarding the German dual VET model's implementation in Costa Rica. Still, a dual VET law was passed: several months after the breakdown of the tripartite social dialogue table, the Costa Rican parliament on its own approved Law No. 9728 of 12 September 2019, "Ley de educación y formación técnica dual".

The article analyzes the arguments and perspectives developed and proposed by Costa Rican business representatives during the social dialogue process intended to discuss and elaborate on a national policy of dual training. The main objective is to understand the political and technical conceptualization of the organization and the structure of a Costa Rican workbased learning system, from the business sector's perspective. The political and technical concepts analyzed were expressed through different discourses (and argumentative strategies) during the tripartite dialogue table in 2017 and in subsequent interviews conducted. Therefore, the research question is: What concepts did the business sector deploy during the social dialogue regarding the transfer of the dual VET model?

This article is a first approach to the study of Costa Rican business culture and subjectivity around professional training. It will be accompanied by two other forthcoming papers discussing the unions' arguments and perspectives and those of the state during this process.

\section{Theoretical framework}

In this section, the literature review attempts to provide an overview of the research activities within Germany regarding dual VET transfer (sub-section 2.1) as well as the discussion in Latin America, particularly in Costa Rica, surrounding the implementation of foreign public policies (sub-section 2.2). Finally, the theoretical framework of the analysis of the argumentation strategy is presented (sub-section 2.3).

\subsection{Transfer the dual model}

As the article focuses on the transfer of the German dual VET model, the review is limited to articles about transfer of the German dual VET model only, omitting e.g. publications about 
the transfer of the Austrian (Langthaler, 2015) or Swiss dual VET models (Strahm, Geiger, Oertle \& Swars, 2016). Here, the literature on the transfer of the German dual VET model can largely be separated in two groups: literature in favor of the transfer and literature against it (Eckelt, 2018, pp. 194-197). For a broader overview, the bibliography of the BIBB, regarding international collaboration and transfer in vocational education and training was analyzed (Linten \& Prüstel, 2019). Even though the bibliography is far from complete, it sheds light on the main topics of discussion in the field. In 48 documents published between 2009 and 2019 two additional categories were found: literature with how-to knowledge on successful transfers (as example Strittmatter \& Böhner, 2019) as well as literature analyzing business models in the framework of the transfer of dual VET in the global education market (Hilbig, 2019; Peters, Gessler \& Kühn, 2019). For the scope of this paper, the first two categories are sufficient.

While arguments in favor of transferring the model try to specify conditions under which it can be successful, the arguments against the implementation state that the transfer itself is not possible. In the critical research perspective within Germany, the dual system has been referred to as "export champion without sales" (Euler, 2019, pp. 315-329) or "non-exportable export champion" (Münk, 2017, p. 10) both referring to the argument that to date examples for a successful transfer of the German model on the macro level are still missing (Euler, 2013, p. 322) and the sustainability of transfer projects evaluated negatively (Stockmann, 2019, pp. 142-143). In particular, Münk (2017, pp. 4-5) argues that the dual VET system is the outcome of particular circumstances in Germany's unique history and as the history cannot be transferred the dual ET model cannot either. The development was the consequence of social, economic and political change. A transfer of this system is therefore a reversal of cause and effect-despite the positive outcome of the dual training model in Germany. Acknowledging these criticisms, the German government argues that the system itself should not be transferred, but rather, certain elements, according to the partner country's particular needs (BMBF, 2013; for an analysis, see Baumann \& Krichewsky-Wegener, 2019, p. 252). This view is also supported by several researchers who argue that a transfer of certain elements is possible (Euler, 2013) or specify conditions and/or develop typologies that need to be considered for successful transfers (Pilz, 2016, pp. 11-33; for the case of Costa Rica, see Grein, 2018). 


\subsection{Transfer to Latin America}

In Latin America, the transfer of public policies has a long history, especially in economic, social, military and fiscal policies. Latin America borrowed from Europe and the United States a good number of institutional designs that, put into practice, proved not to yield the expected results from the experiences of the models. This is because the models, further stylized by academic literature and political marketing, are always the product of particular socio-historical and cultural experiences. The issue is not, therefore, the importers' lack of will, inefficiency or other limitations, but the gravitation of the scenarios in which the institutional schemes are to be implemented and the belief systems, attitudes, customs - the "spirit of the laws" as Montesquieu called it-of the people who are expected to behave as the models prescribe (Vilas, 2011, p. 7).

Following Vilas (2011), the ostensible "successes" or "failures" of policy transfers rely not only on the characteristics of the policies themselves but on the contexts in which these policies are to be implemented. In other words, the analysis of a public policy transfer (or, at the very least, some of its components) in a new social context requires an in-depth analysis, not only of the forms and procedures in which the transfer is generated, but also of the political justifications and socio-cultural scenarios that justify the import and/or export of public policies. Since the 1980s (Láscarez, 2017, pp. 50-58) transferring dual training policies or models inspired by the German systems to different states of Latin America has gained popularity in the fields of technical education and vocational training.

To adequately assess the local context, it is relevant to analyze the preponderant social narratives among different social actors within this context, as the degree of autonomy of the country importing policies is expressed, among other things, in how a public policy is justified and in ideas around how it should be implemented, adapted and adjusted. Such an analysis does not only include the analyses of the favorable or unfavorable speeches the local actors may have on a given public policy, but also the underlying arguments that govern a certain vision of the world that justifies the arguments on those technical and political aspects of a possible transfer to the local context or, on the other hand, a vision of the world that justifies the arguments against such a transfer.

For the analysis of the process of policy adoption from abroad, the term "tropicalization" is used from two points of view: (1) Tropicalization as a discourse resource used by different social actors to indicate the need for tropical countries to "to adapt" or "to adjust" policies coming from the Global North (particularly United States and Europe). In this sense, the term 
"tropicalization" is not used by social actors from a technical point of view, but rather from a political one, insofar as the elements to be tropicalized are adjusted to the particular political interests of the interlocutors. In other words, tropicalization is understood as a narrative resource that suggests adaptation not from the context of general discussion, but from group or individual interests. (2) Tropicalization is understood from a theoretical point of view ${ }^{7}$, in which culture and business subjectivity are expressed through different forms of dialogue, tensions, conflicts, interests and social practices. Tropicalization is a way of representing these tensions, conflicts, interests and social practices around the public policies that one wishes to import. Specifically, when representatives of business groups express the need to tropicalize a reference model (the German dual model), what they are really expressing are political interests and motivations that are clearly reflected when arguing the reasons why a certain part of the model should be "tropicalized". For example, when they refer to the need to "tropicalize" union participation "because German unions think differently than Costa Ricans" (Interview 3) or that the payment of subsidies or salaries to apprentices should be tropicalized because "Costa Rica does not have the financial capacity or the automobile companies of Germany" (Interview 5).

\subsection{The argumentation as an expression of reality}

In his book The Uses of Argument (Toulmin 2003; 2007), inaugurates a new analytical paradigm, called the "inferential paradigm" allowing readers to concentrate the analyses of different reasonings not as syllogisms or, as deductive logic based on the validity and formal consistency of the argument, but as practical problems of reality. Toulmin (2007, pp. 17-18) indicates that these practical problems do not arise within the science of logic, but only when one withdraws oneself for a moment from the technical refinements of the subject, and inquires what bearing the science and its discoveries have on anything outside itself-how they apply in practice, and what connections they have with the canons and methods. That is, in ordinary life, everyday discourses are not constructed from syllogisms, but rather what is judged is the solidity and strength with which one intends to conclude something.

The "practical evaluation of arguments" (Toulmin, 2007, p. 18) in everyday life refers to the way in which people use flexible inference strategies-without formalism - that is, commonsense reasoning that aims to meet the conditions of truth in which that reasoning arises (Fuentes \& Santibañez, 2014, p. 535).

\footnotetext{
${ }^{7}$ Although no theoretical approaches to this concept have been found, a conceptual description has been made based on the reflections of the authors. 
In the book An Introduction to Reasoning (Toulmin, Rieke \& Janik, 1984, p. 14), Toulmin defines argumentation as "the whole activity of making claims, challenging them, backing them up by producing reasons, criticizing those reasons, rebutting those criticisms, and so on". This dynamic of resonance is developed in fields of reasoning (Toulmin, 2007, p. 29) that differ in the possibility of presenting more or less rigorous arguments-for example, the field of argument of theoretical physics is different from that of psychology. An "argument" in the sense of it being a "train of reasoning," is the sequence of interlinked claims and reasons that, between them, establish the content and force of the position for which a particular speaker is arguing (Toulmin et al., 1984, p.14).

The field of argument is the political field; the arguments are constructed by economic actors involved in the elaboration of education policy. The object of the study is the claims individual speakers have, how they support and defend their claims as or even before they are being criticized. For Toulmin, the concept of field of argument is directly related to two other elements: relevance and context. These elements are fundamental to any theory of argumentation "since it is almost impossible to understand argumentative activity far from the circumstances, the place, the right moments, the time in which it occurs" (Mercado, 2016, p. 15). In the context of discursive production, the force and function of each part that constitutes the argument should be uncovered (Toulmin et al., 1984, p. 11). In this sense, the construction of an argument is born as a social iteration between the context and the person who is speaking.

Toulmin's contribution on the inferential and flexible construction of arguments is linked with the study of the social conditions of discourse production in Critical Discourse Analysis (van Dijk, 2005, pp. 253-283), since it understands the production of discourses as social processes framed under certain socio-historical structures (Wodak \& Meyer, 2013, pp. 29-33).

The socio-historical structures are usually ignored in the policy transfer, and it is these socio-historical structures that have been long-ignored in the development of a critical vision within academic circles. This is because a rational and technical vision of the problems of transfer still persists and is opposing a vision centered on the characteristics, divergences and social contradictions of the various social groups that understand and experience differently the meaning of "transfer", including the potential for both social conflict and the benefits associated with this process. In other words, "the concept of power, the concept of history and the concept of ideology" (Wodak \& Meyer, 2003, p. 19) have been ignored. Just by taking these concepts into account, it becomes possible to understand how social structures produce 
speeches and vice versa. As van Dijk (2005, p. 21) mentions a discourse is also a practical, social and cultural phenomenon. The analysis of discourse as permanent social action also concentrates on order and organization. The discursive use of language consists not only of an ordered series of words, clauses, sentences and propositions, but also of sequences of mutually related acts.

According to van Dijk, the speaking subjects are also representatives of social, organizational, institutional and cultural categories. In this case, the study of the business sector's discourse at the dialogue table adopts special relevance, as they are representatives of a social group (employers, companies). The discourse then becomes a representation of ideas, beliefs, values and interests within a wide universe of other discourses. The context of speech production is fundamental to consider, as the speakers both construct and exhibit the roles and identities of what they represent (van Dijk, 2005, p. 22). In other words, the discourses and arguments analyzed here represent not individual actors, but the process of social selection that has chosen somebody as the representative of a group, demanding that the emitted speech represents those groups in the essential (Chilton, Schaffner \& van Dijk, 2005).

\section{Methodology}

In this section, the way the study was carried out is outlined. Therefore, firstly, the approach is introduced (sub-section 3.1), before the unit of analysis is presented (sub-chapter 3.2). Then, the research method is carried out (sub-section 3.3). As a last step, the analysis is described (sub-section 3.4). The research project was carried out between June 2018 and January 2019.

\subsection{Approach}

The methodological approach of the present article is based on the hermeneutic contributions of the Critical Discourse Analysis. As such, the methodological perspective of the study is qualitative. Basically, discourse is an expression of social interaction (van Dijk, 2000). In this sense, the expression of a discourse is the manifestation of political interests and positions, of diverse forms of intersubjectivity. To legitimize a discourse, the speaker makes use of a series of argumentative strategies that try to convince or appear convincing to the listener.

The arguments in the speeches of the business actors are the units of analysis in this article, since they express the business sector's concepts about dual vocational training as a 
political and social project. Specifically, the Argumentative Analysis of the Discourse of Stephen Toulmin (2007) has been used to carry out critical analysis of arguments. In order to clarify the construction of an argument, Toulmin developed a way to illustrate arguments (presented in Figure 1): according to Toulmin the starting point for any argument is data (D, "Anne is one of Jack's sisters") and the goal of any argumentation structure is the conclusion (C, "Anne now has red hair"). On the way from the data to the conclusion supporting material was found, expressed as warrants (W, "Any sister of Jack's may be understood to have red hair"). While it is possible to have more than one warrant, it is also possible to further secure the warrant with a backing ( $B$, "All of his sisters have been previously observed to have red hair"). Even considering all warrants and backings, in most cases, the conclusion cannot be derived in a way of a scientific law; rather, certain rebuttals ( $R$, "Anne has dyed/gone white/lost her hair") will have to be excluded (Toulmin, 2003, pp. 115-118).

Figure 1

Toulmin: Basic layout of arguments in the use of arguments

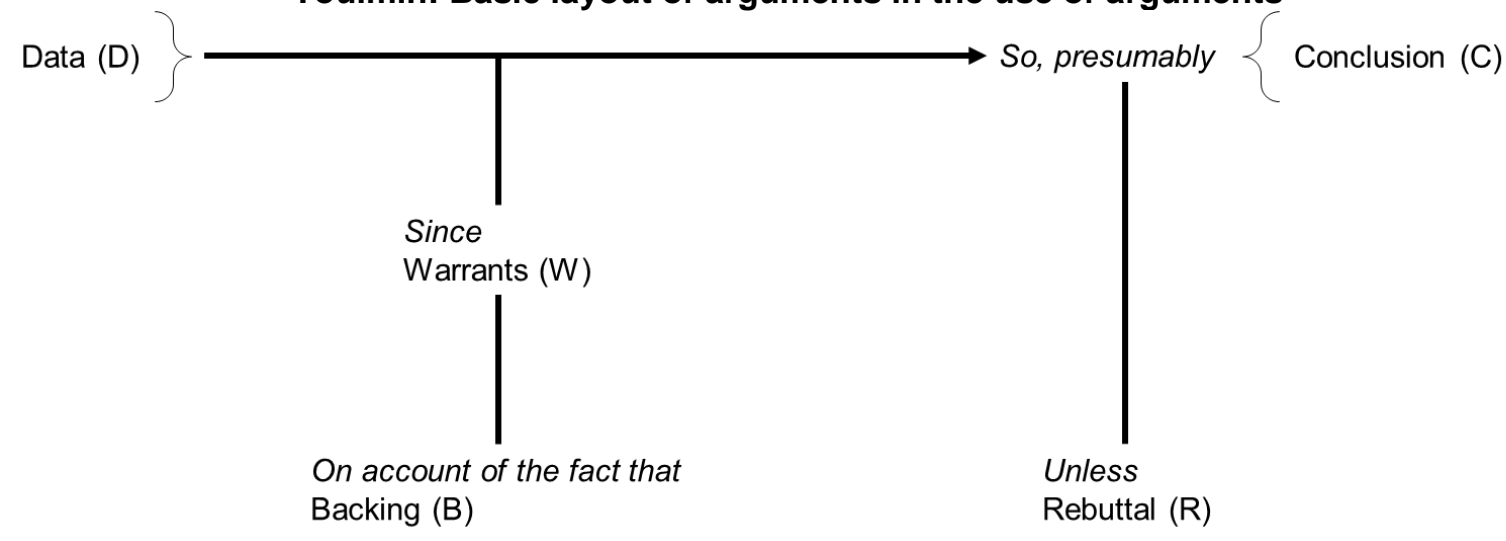

Source: Based on Toulmin (2003, p. 97)

\subsection{Unit of analysis}

This article is part of a more extensive research process in which the social actors that participated in the National Tripartite Dialogue Roundtable ${ }^{8}$ for the promotion of dual training in Costa Rica were interviewed, namely the state, trade unions and the business sector. In addition, the moderator of the social dialogue, a representative of the ILO, was interviewed. For this research article, two actors who legitimately represented the Costa Rican business sector during the dialogue table on dual training participated in the interviews: one interview was

\footnotetext{
${ }^{8}$ Altogether there were ten sessions of the dialogue table, on the following dates in 2017: February 27, March 27, May 5, May 19, May 26, June 9, June 23, July 21, July 31 and September 1.
} 
conducted with a representative of a business chamber and the other with a representative of a business association. In addition, due to his experience in education and vocational training in Costa Rica, the first author was a consulting member of the roundtable by preparing a study on the costs and benefits of dual training for businesses. Thanks to this role, he had the opportunity to participate in five working sessions of the dialogue table. The units of analysis are summarized in Figure 2.

Figure 2

Costa Rica: Actors' interaction during the tripartite social dialogue process and during the research.

Source: Own creation, 2019

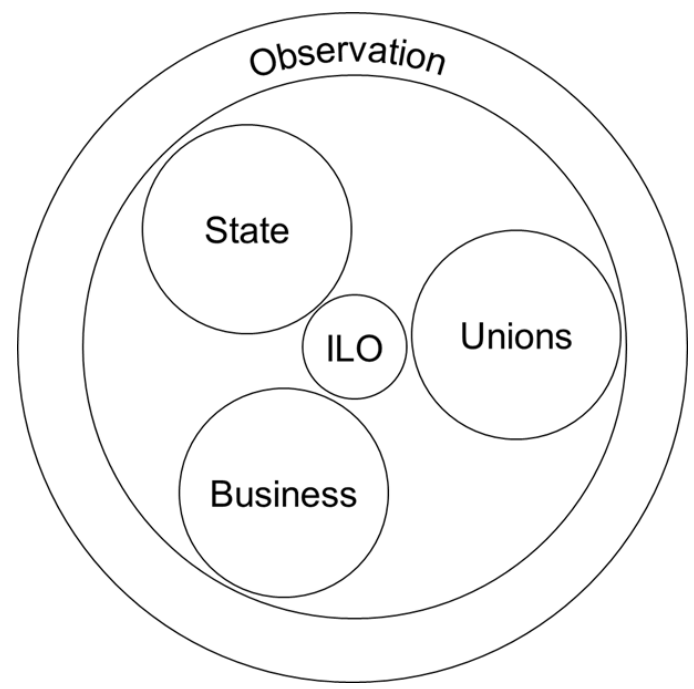

\subsection{Research Method}

A qualitative instrument was used such as the semi-structured interview (the guide can be found in the appendix of this paper) directed at the two business representatives. The first objective of the semi-structured interviews was to identify the concepts of the actors as those of representatives of business groups, that is, as spokespersons of other chambers and business associations. The second objective was to emphasize on the reasons why the enterprise groups had one or another position on a certain topic around the dual training. In attempting to put forward solid reasons, the interviewees resorted to different steps (conclusions, data, warranties, rebuttals and supports) to try to express a convincing argument.

The semi-structured interview was used because, although it is based on planned questions, it offers greater flexibility and capacity to adapt to the motivations of the interviewee, allows for the clarification of terms and concepts and the identification of ambiguities, thus 
reducing formalisms, which limits the capacity of the interlocutor (Díaz-Bravo, Torruco-García, Martínez-Hernández \& Varela-Ruiz, 2013, p. 163). The semi-structured interview gave the possibility for the interviewees to offer their points of view and the argumentative reasons for their political, economic and social positions on the implementation of the dual training, i.e. it allowed the collection of the qualitative data to then proceed with the critical analysis of the argumentation.

\subsection{Data Analysis}

The interviews were conducted on site. Participants were asked for permission to record the interviews and then transcripts were made based on a verbatim transcript of the interview. Once the text was obtained, i.e., once the speech was obtained as an expression of reality and its respective arguments, the main line of arguments was condensed and each speech was assigned the categories of analysis - data, warrants, backing, rebuttal and conclusion (see also Figure 1). The framework for the analysis of the arguments/argument strategies was made following the Toulmin procedure (Figure 3 and Figure 4). In this way, two models of argumentation were extracted, which are framed in the objectives of the study. The objective was to reveal the missing links and problems of the argumentation structures in order to better understand the logic behind.

\section{$4 \quad$ Results}

In the following sections results of the analysis are presented. First, an outline of the business sector's views regarding the implementation of the German dual VET model is made (sub-section 4.1). Second, the Costa Rican business sector's views on how the German model needs to be modified in order to align with Costa Rica's unique socio-economic environment is presented (sub-section 4.2).

\subsection{The justification for the implementation of the dual training policy in Costa Rica}

This first concept discusses the arguments justifying the importance of implementing dual training in Costa Rica from the business sector's point of view. The arguments that justify the need for implementation have been placed first, since they allow insights into the vision of employers concerning dual training. According to Toulmin (2007, p. 23), "justification" is the step made by the speaker between the conclusion and the data presented in order to conclude 
something. Toulmin suggests that before reaching a conclusion, it is necessary to pass through intermediate phases, whose retrospective and justificatory character serves to support the ensuing conclusions. For both interviewed representatives of the business sector, the justification for why Costa Rica should implement a dual training system are consensual. In the speakers' opinion, two social problems justify the need to import the German dual training system. First, there is the high unemployment rate, particularly among youth, observed in Costa Rica since 2010: "the state has a natural inability to employ workers" (interview 3). Second, the business sector cites the inability of VET institutions to respond to the needs of the labor market: "the institutions do not know how to and cannot respond to the business needs that are expressed in a very diverse way in the national territory, that is, the state cannot really offer qualified labor on its own" (interview 3).

The business sector argues that not only is the state unable to provide qualified labor, but VET institutions cannot identify the training needs of micro-, small- and (to some extent) medium-sized businesses. The benefits of demand-oriented training appear available only to large companies

"Because, on the one hand, in small companies, the dynamics of hiring new personnel is not based on technical studies, but on the ideas and general knowledge that the owners have of the labor market - which is very limited - and on the other hand, because training institutions do not have the resources to work with $80 \%$ of the country's business park" (interview 5) ${ }^{9}$.

In accordance with Toulmin (2007, p. 30) the arguments' function is to justify the ultimate assertion or conclusions. In the case of the speakers, the assertion made is that "the only way in which the economic sectors of Costa Rica can compete and reduce unemployment is through dual training" (interview 3). It is usual for speakers to strengthen their arguments and convince their listener that the affirmation is logical to anticipate and present possible rebuttals to their conclusions. The expressed exception ("unless Costa Rica grows more that $4 \%$ of the GDP every year to create the minimum required jobs") includes a possible counterargument in the argumentation strategy to strengthen itself. In this case, the employers' representatives mention that

${ }^{9}$ Original version in Spanish, translated by the authors. 
"The only way that the business sector of Costa Rica can compete and reduce unemployment is through dual training", and "that the country grows at a sustained rate of $4 \%$ each year, since each percent point of growth of the gross domestic product represents 60,000 new jobs and Costa Rica would need 240,000 new jobs every year" (interview 3$)^{10}$.

Figure 3

Costa Rica: Argumentation strategy of the business sector for the implementation of dual VET 2018

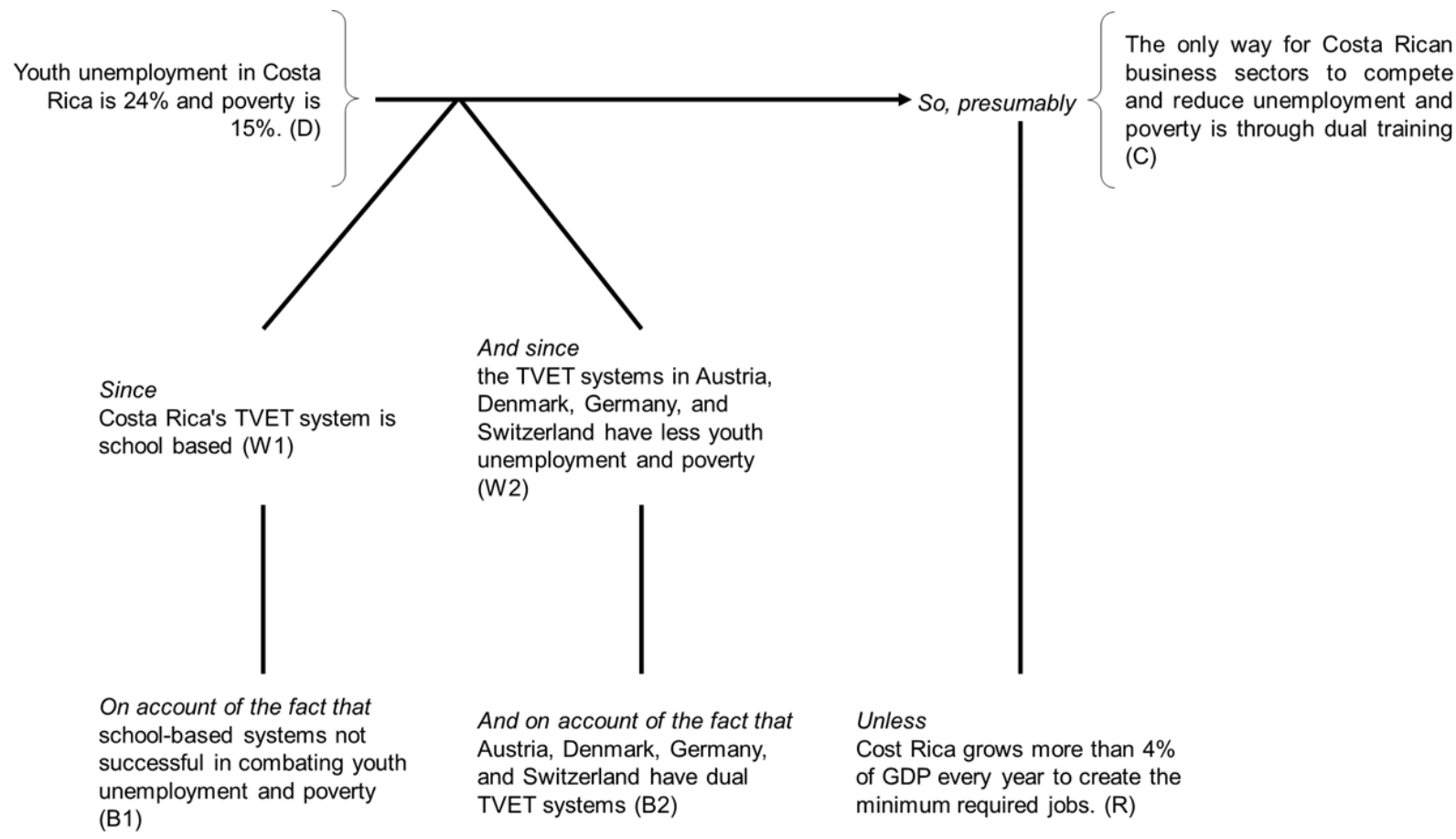

Source: Own creation based on interviews with key actors 2019.

The idea that dual training aims at reducing unemployment could have different educational effects, for example, on the teaching methods (didactic-pedagogical) that have to be implemented both in the company and in the educational center. One of the first things that would change at the curricular level if a dual training policy is implemented is the shared curriculum between company and school, i.e. a reorganization of the functioning of the learning process, of the learning methods, the inclusion of other actors in the training and the idea of alternation. If a dual education policy is designed under the slogan of reducing unemployment and not to improve the acquisition of labor, social and personal skills, then there may be an

\footnotetext{
10 Original version in Spanish, translated by the authors.
} 
imbalance in educational planning, especially since unemployment is a problem caused by multiple factors. In other words, an educational policy of dual training must contemplate at least four functions where the economic labor function is only one: social function cultural function, economic function and political function ${ }^{11}$ (Rützel, 1995, pp. 109-118).

\section{2 "Tropicalization" of foreign public policies}

As we have previously described the concept of tropicalization, in the present article, it refers to the term used by the interviewees to indicate the need "to adapt" the German model to the Costa Rican context. But what does it mean "to adapt" (tropicalize) a model? What exactly does the tropicalization of the German model refer to? For the business actors, the term refers to a process of political adaptation, it refers to an opportunity to shape a project to ensure that group interests and objectives are met. Therefore, tropicalizing a project does not necessarily refer to the changes and adaptations that are made to a project due to technical analysis, but rather to technical adaptations with a political basis. This is exemplified when employers say that "we don't have the big German companies, nor do the business chambers bring all companies together" (Interview 3), or that "countries' trade union and business cultures are different" (Interview 5) so that salaries and student grants need to be analyzed differently. Another characteristic of "tropicalization" is that the criteria for adaptation can differ significantly from one actor to another or from one interest group to another. The differences in criteria are clearly expressed through the narratives of the actors, understood as ideological characteristics that order, structure and complete a vision of reality (Reano, 2014). The critical approach of such narratives can highlight the "illusions" and "fictions" of the story itself and with respect to the system it aims to build (Žižek 2003, cited after Reano, 2014). In the case of Costa Rican entrepreneurs, the narrative expressed reveals a vision of the role and functions of technical and vocational education and training, while also manifesting ideological differences in relation to other actors.

For example, the idea of the interviewees is that Costa Rica should copy the German model of dual training, but by adjusting two components of the German model: (1) public-private

\footnotetext{
11 The social function is related to the curriculum considering the social-historical context of the educational process in order to e.g. transform it. The cultural function responds to the different forms of integration of young people in society through relevant cultural values (migrants, refugees, vulnerable young people and women in technical careers traditionally enrolled by men). The economic function is related to the integration of people in a decent labor market and the improvement of business competitiveness. The political function is the articulation of the different social, economic and political actors for the improvement of education.
} 
partnership would be considered more efficient than tripartite governance and (2) trainees are not workers.

Figure 4

\section{Costa Rica: Argumentation strategy of the business sector for the "tropicalization" of dual VET} 2019

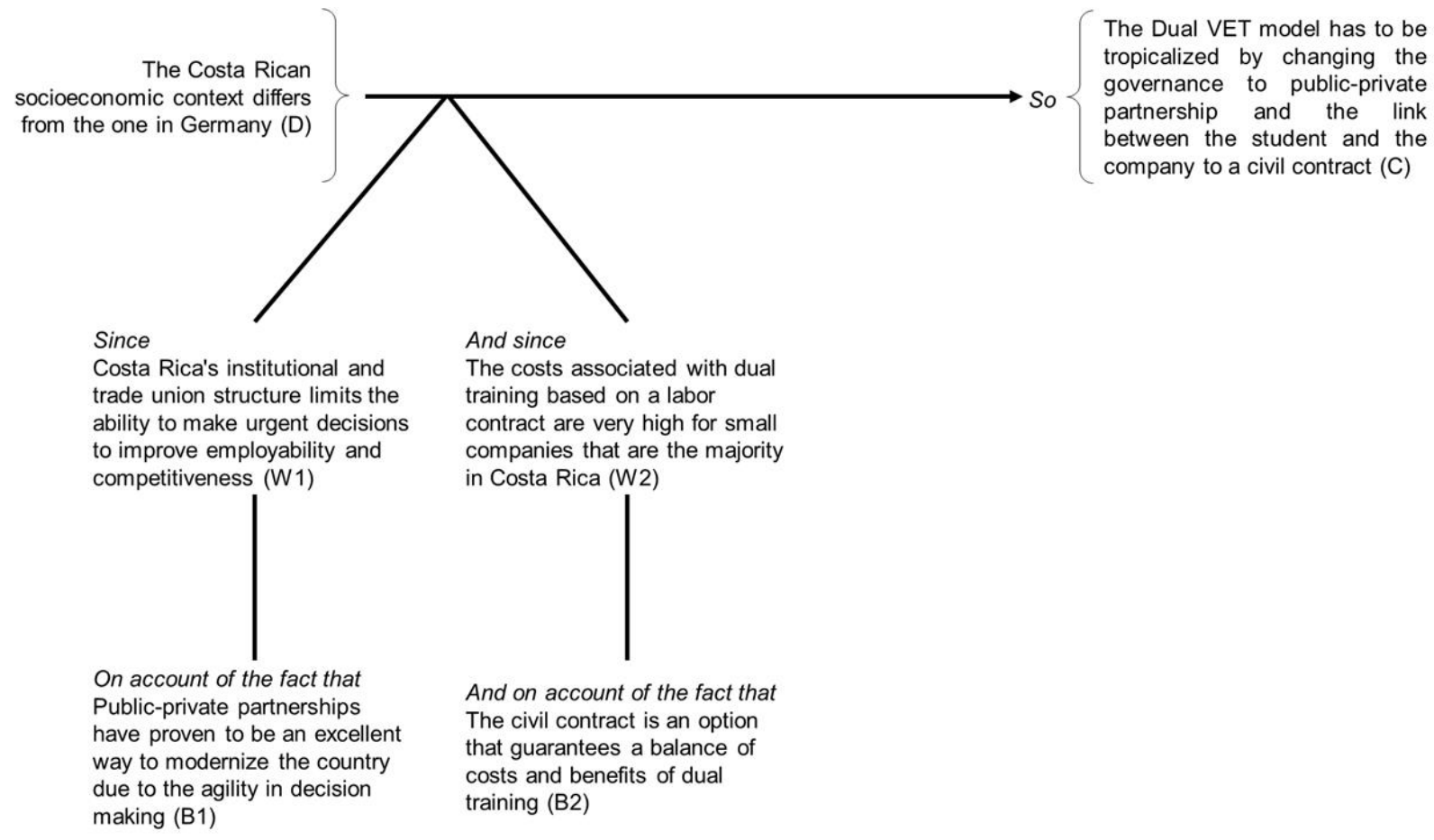

Source: Own creation based on interviews with key actors, 2019.

\subsubsection{Public-private partnership, not tripartism}

One of the central topics of the dialogue process was related to the governance and structure of the dual training system. From the business perspective, VET institutions and trade unions cannot make "urgent decisions" on the needs of the productive sector. This point, according to the employers, proved to be key to differentiating it from unions and VET institutions: While unions and institutions defended tripartite governance, the employers fought for a bipartite governance, where the union participation was only consultative. The argumentative pursuit of political pressure, power and control over another is called "social power" or "act of social power" (van Dijk, 2000, p. 40), which establishes relationships between social groups or institutions, differentiating between them and establishing mechanisms of control and ensuring the achievement of certain goals. This category is particularly relevant in the discussion of dual training and the type of governance it requires according to the process 
of "tropicalization", as this discussion is basically related to the historical relations that have developed between the social actors in VET.

In general terms, social dialogue is the discursive exchange between social actors, the problem is how to understand the social and historical configuration of discourses (Prosser \& Perin, 2015; Romero, Elgoibar, Munduate, García \& Euwema, 2017). In the case of tripartism, these discourses imply not only their simple exchange, but also their mutual confrontation, as different speakers provide opinions on issues on which they disagree (García Arce, 2002). The conflict that underlies tripartism in this case is the idea that the entrepreneurial discourse seeks to avoid, considering it "a loss of time, because qualification-needs change every year, every month, and no time can be lost discussing issues on which neither party will agree" (interview 3).

For entrepreneurs, an alternative to tripartism is the incorporation of "public-private partnerships" as a management model for dual training. This concept will be analyzed in the following section, since it is in itself a political and technical management conception.

As asserted by Toulmin, the argumentative process must go through intermediate levels, guarantees, backups, data and justifications that strengthen the conclusion or claim being made. The act of providing alternative solutions is part of the argumentative process. According to business sector speakers, the most appealing alternative to the German model of dual training is that of a public-private partnership (interview 3; interview 5).

Private sector representatives argue that the private sector, lacking bureaucracy and "legal constraints" (Interview 3) is more capable than state institutions at addressing the problem of unemployment and increasing the conditions for business competitiveness. Business representatives maintain that proposing public-private partnerships as a way of managing dual training is caused by the inability of the government to provide qualified labor, reduce unemployment, reduce informal employment and face the challenges of digitalization and its social, economic and cultural consequences on its own.

The transfer of tasks between the state and enterprises must become the central focus of the dual training policy if the needs of the labor market are to be truly met, speakers assert. The representatives of the business groups argue that companies cannot replace the government in its social function, but the government can allow them to lead and coordinate the "strategic" issues of the economy and work.

The role of the state and the private sector around issues of public interest such as education has generated strong forces in Latin America (Gvirtz \& Oría, 2010) because this area 
is susceptible to certain forms of privatization of education and the social consequences these processes portend. Other authors try to overcome the "public-private" juxtaposition and propose analyzing the real mechanisms of coordination, management, levels and areas of "alliances" (Ball, 2007). What is needed is a study of the forms that public-private alliances will take in technical and vocational education and training in Costa Rica in the coming years.

\subsubsection{Apprentices as scholars, not as workers}

Another central theme in the discussion on dual training was the type of social link that would define dual training - that is, the definition of roles between the VET institution, the student and the company. While the type of social relationship for dual training in Germany is of a legal-labor nature, the Costa Rican business vision held that the relationship that should define the learning relationships ought to be of a legal-civil nature.

The justifications and backing for this conclusion, according to business criteria, are related to a general definition of the costs and benefits of dual training. In addition to the costs related to on-the-job training (including materials, equipment and instruction), these costs are related to Costa Rican labor legislation, which includes an employer's contributions for employee pensions ${ }^{12}$, severance pay, a salary (or stipend) for apprentices, and the labor rights linked to the "Ley de Protección al Trabajador" [Ley 7983] and "Reforma Procesal Laboral" [Ley 9343].

La Reforma Procesal Laboral was approved in 2015, coinciding with the beginning of the debates on dual training in Costa Rica. These reforms caused resistance among employers due to the broad legal protections it extended to workers, protecting them against any discrimination, and ensuring equality and the legality of strikes among other protections. ${ }^{13}$ In Germany, the "apprenticeship contract" is a binding legal document between the representative of the educational center and the company, allowing the student to develop the dual training plan in real environments. As an alternative to this, the business sector proposed that the student should receive a stipend instead of a salary ${ }^{14}$. For this purpose, they proposed to create a special scholarship fund for dual training, financed by INA. This scholarship fund was justified

\footnotetext{
12 The contributions to obtain a pension in the regime of "Invalidez, Vejez y Muerte" is $10,66 \%$ of the salary, distributed in the following way: $5,25 \%$ by the employers, $4 \%$ by the workers and $1,41 \%$ by state:.

13 See more information in the following http://www.mtss.go.cr/elministerio/despacho/rpl/Reforma \%20Procesal Laboral.html, accessed on June 30, 2020 14 It is important to mention that the dual education law approved in September 2019 does not establish an employment relationship between the apprentice and the student.
} 
by the fact (data) that all enterprises, except for agricultural enterprises, must contribute $1.5 \%{ }^{15}$ of the payroll to the financing of the INA. In other words, according to the employers' criteria, an apprenticeship labor contract, instead of a civil contract, would involve a double financing of dual VET. The $1.5 \%$ contribution that companies must pay to finance the INA is an argument that the business sector should no longer pay a salary or stipend to students.

For their part, the trade unions argued that the learning contract should be of a labor, and not civil, nature precisely to guarantee students the recognition of their productive contributions in the workplace. For the trade unions, the labor contract was only the real way in which dual training could contribute to reducing unemployment and improving young population's participation in the labor market in Costa Rica.

These arguments reflect how social power relations, understood as differentiation and control, are expressed on the one hand by categorizing the role of other VET stakeholders, trade unions and VET institutions, and on the other hand by the differences of opinion of stakeholders regarding the legal status of the apprentice. This question is the key in revealing that the German model is not identical to that of Costa Rica, so it must again be "tropicalized".

For employers, the "tropicalization" of the German dual VET model meant stripping the labor character of the apprenticeship in order to avoid the financial (and above all legal) repercussions of turning the student into an apprentice. It could therefore be said that the general consensus on this point is that students do not work, which is why they are not workers, and the regulations governing the working relationship between a "worker" and a company would not apply in this case (even though the speakers always refer to the need to migrate to work-based learning systems).

\section{Conclusions}

The tripartite dialogue table, as a mechanism for political concertation, was the starting point for the research project described in this paper. Within the dialogue, the state, the business sector, the trade union sector and experts discussed different aspects and components of a dual training system "a la tica" based on the German dual training system. The goal of this dialogue was to arrive at a shared understanding of how this model or a part

\footnotetext{
$151.5 \%$ of the amount of the payroll of the private company, from all economic sectors with at least five workers. $0.5 \%$ of agricultural enterprises with more than ten workers. $1.5 \%$ of the total amount of payrolls of autonomous and semi-autonomous institutions and state see https://www.ina.ac.cr/SitePages/Faq.aspx\#: :text=\%C2\%BFC\%C3\%B3mo\%20se\%20financia\%20el\%20Instituto,c on\%20cinco\%20trabajadores(as), accessed on June 30, 2020.
} 
of it might be transferred to Costa Rica in order to obtain the social, economic and educational benefits experienced in Germany and other countries with a similar system. The political objective was that the education policy would be based on the technical results of the dialogue table. However, the tripartite social dialogue did not have the expected outcome: no tripartite consensus was reached on the main characteristics of the Costa Rican dual model. In this sense, it is important to point out that the dialogue table was born in an intense social and political conflict over the spirit of an educational policy of dual vocational training. Dialogue tables as a political tool can reduce differences and generate consensus, in this case on an issue that for decades generated strong union and political opposition, and many business motivations.

The issues on which there was no consensus were analyzed by reconstructing the arguments that are part of the official business discourse which, on the one hand, is an outcome of social practice and, on the other hand, the base for continued social practice (van Dijk, 2005). Analyzing the arguments through Toulmin's model (Toulmin, 2003, pp. 87-131), two main lines were found. First, it was reasoned why the dual VET model ought to be implemented at all; and secondly, why it should be tropicalized to fit the socio-economic and cultural context of Costa Rica. For both lines of argument, an idea of the logic of the argument is given. As can be seen, there is an economist argument that justifies the need for dual training. Educational arguments and justifications are not part of the business reasoning, so the absence of this type of reasoning in the design of a public policy of dual training could be counterproductive, because without an argument that frames the educational and institutional situation of the functioning of technical education and vocational training, it will not be possible to improve aspects of success such as the pedagogical role of the company as the nucleus of learning.

Another relevant conclusion of the study is the understanding of the arguments that justify the idea that the expected results at the social, economic and educational level of dual training should be adjusted to the real conditions of the country - in other words the German model has to be "tropicalized". However, the real conditions of the country are defined and determined by the political-ideological boundaries and the concrete interests of the groups that express them, in this case the business groups. This is also evident in the absence of technical studies offered by the actors.

In other words, it was outlined how the development of a two-folded argumentation strategy where only the implementation of the dual VET model will assure that Costa Rica can compete in a worldwide context and therefore reduce the youth unemployment rate. And 
secondly, that this can be achieved by changing the dual VET model in a way that its core characteristics are missing - by replacing the tripartite governance to a public-private partnership and change the status of an apprentice to the status of a scholarship holder. In this way, the implementation process could be viewed as a window of opportunity for the business sector to reach goals not necessarily related to policy transfer itself.

Another relevant conclusion is associated with the last paragraph: for the business sector, the discussion on the design of a public policy of dual training has taken place within the framework of political struggles related to the transformations of the Costa Rican state (fiscal crisis, public employment, reduction of the state, economic liberalization and restructuring of educational institutions), specifically with the trade union sector. This means that the debate on dual training has been not only an educational, economic and/or employment debate, but a broader debate to try to impose certain political agendas (visions and interests) in the framework of a political confrontation at a sectoral but nationwide level.

The discursive and argumentative structures analyzed in this paper express the interests and motivations, that is, the rationality of the business sector in the design of the dual training educational policy. The educational implications that can be derived from this rationality fall both on the students of the VET system and on the companies that have expectations about such a training. Dual training implies a series of changes in both the structure and organization of VET institutions, for example, the financing of the system and the channels of communication with the economic sectors. At the pedagogical and didactic level, alternation implies a constant and agile updating of the teaching techniques of technical careers, of the methods of evaluation in the company and in the training center as well as of the way in which certain competencies and skills are developed and acquired. It is too early to know the educational implications in the school and in the company, but this research sheds light on how the technical education policy is being rationalized and how the educational and social profile of students in the VET system in Costa Rica is being justified.

In further research, the results need to be compared also with the arguments of the state and the unions within the tripartite dialogue period. Parallel of widening the empirical base of the analysis by incorporating the state and the unions, also the theoretical point of view could be changed in order not to focus on the conception of the implementation of the German dual VET model but on focusing on model itself was chosen. This could be done by an neoinstitutionalist approach focusing on the perceptions on the German system within the Costa Rican VET discourse. 
The research does not analyze the legal characteristics nor the educational consequences of the Dual Education Law approved after the period of analysis of this study. In that sense, it is recommended that future research incorporate the impacts on both the labor market and the pedagogical implications of the law. It is possible that with the new dual training law, teachers, administrators and students will begin the transition to a new legally regulated educational paradigm and will require adjustments and improvements in the near future, so that future studies should focus on the effects of the actors directly involved in the learning process.

\section{Acknowledgements}

First and foremost, we thank our interview partners for agreeing to hold interviews with the fist author of this paper. Without them, the article's empirical basis (and thereby the article itself) would not exist. Furthermore, we thank Prof. Dr. Dietmar Frommberger, Osnabrück University, for his advice during the writing process and the flexibility provided within our working environment, so that the collaboration of the two authors could be established. We also thank Prof. Mainor Mora, National University of Costa Rica, Michael Vina, Ph.D., University of Bergen, Luis Diego Soto, National University of Costa Rica and Mauricio Chaves, Osnabrück University, Germany, for their suggestions regarding the theoretical outline. Finally, we thank Patricia Helena Nash for the intensive proofreading of this paper.

\section{References}

Ball, Stephen. (2007). Education Plc: Understanding Private Sector Participation in Public Sector Education. Londres, Reino Unido: Routledge.

Baumann, Fabienne-Agnes., \& Krichewsky-Wegener, Lena. (2019). The internationalisation of VET: German VET providers abroad transfer vs. pragmatism? In F. Marhuenda \& M.J. Chisvert-Tarazona (Eds.), Pedagogical concerns and market demands in VET. Proceedings of the 3rd Crossing Boundaries in VET conference, Vocational Education and Training Network (VETNET) (pp. 251-260). doi: https://doi.org/10.5281/zenodo.2641013

Chilton, Paul., Schaffner, Christina., \& van Dijk, Teun. (2005). Discourse as Social Interaction. Discourse Studies: A Multidisciplinary Introduction (vol. 2). Londres, Reino Unido: Sage.

Díaz-Bravo, Laura., Torruco-García, Uri., Martínez-Hernández, Mildred., \& Varela-Ruiz, Margarita. (2013). La entrevista, recurso flexible y dinámico. Investigación en Educación Médica, 2(7), 162-167. Recuperado de https://www.redalyc.org/articulo.oa?id=349733228009 
Eckelt, Marcus. (2018). Berufsbildungstransfer als Forschungsgegenstand im Rahmen von wissenschaftlicher Projektbegleitung: Eine Reflexion anhand des griechisch-deutschen Pilotprojekts MENDI zur Erprobung dualer Hotelberufe. Zeitschrift für Berufs- und Wirtschaftspädagogik, 114(2), 191-212.

Euler, Dieter. (2013). El sistema dual en Alemania. ¿es posible transferir el modelo al extranjero?. Recuperado de https://sanjose.diplo.de/blob/1520324/8dab2a985c4c9f7ab2a75ddfa35fa516/formacion-dualdata.pdf

Euler, Dieter. (2019). Duale Berufsausbildung - ein Exportschlager ohne Absatz? In M. Pilz, K. Breuing, \& S. Schumann (Eds.), Internationale Berufsbildungsforschung. Berufsbildung zwischen Tradition und Moderne: Festschrift für Thomas Deißinger zum 60. Geburtstag (pp. 315-329). Wiesbaden, Alemania: Springer VS. doi: https://doi.org/10.1007/978-3658-24460-6 19

Federal Ministry of Education and Research [BMBF]. (2013). Strategiepapier der Bundesregierung zur internationalen Berufsbildungszusammenarbeit aus einer Hand. Recuperado https://www.bmbf.de/files/strategiepapier der Bundesregierung zur internationalen Berufsbildungszusammenarbeit.pdf

Fuentes, Claudio., \& Santibañez, Cristian. (2014). Toulmin: razonamiento, sentido común y derrotabilidad. Kriterion: Revista de Filosofía, 55(130), 531-548. doi: https://doi.org/10.1590/S0100-512X2014000200005

García Arce, María C. (2002). Diálogo social sobre formación profesional en España. Montevideo, Uruguay: Cinterfor/OIT. Recuperado de https://www.oitcinterfor.org/sites/default/files/file publicacion/aporte9.pdf

Gessler, Michael., Fuchs, Martina., \& Pilz, Matthias. (2019). Der internationale Berufsbildungstransfer im Lichte der deutschen Berufsbildungsforschung: Wie der Geist aus der Flasche. In M. Gessler, M. Fuchs, \& M. Pilz (Eds.), Internationale Berufsbildungsforschung. Konzepte und Wirkungen des Transfers Dualer Berufsausbildung (pp. 3-10). Wiesbaden, Alemania: Springer VS.

Grein, Julia. (2018). Educación Dual en Costa Rica: Herausforderungen und Möglichkeiten eines Berufsausbildungssystemtransfers. Unpublished manuscript. Recuperado de https://www.kas.de/es/web/costa-rica/einzeltitel/-/content/educacion-dual-en-costarica-herausforderungen-und-moeglichkeiten-eines-berufsausbildungssystemtrans

Gvirtz, Silvina., \& Oría, Angela. (2010). La relación entre el Estado y la sociedad: Alianzas público-privadas para la mejora educacional. Revista Iberoamericana de Educación, (54). doi: https://doi.org/10.35362/rie540541

Heller, Patricia., Grunau, Janika., \& Duscha Katharina. (2015). Das Konzept "Beruf” ins Ausland transferieren? Eine kritische Perspektive auf den deutschen Berufsbildungsexport. Berufs- und Wirtschaftspädagogik - online, (29). Recuperado de https://www.bwpat.de/ausgabe/29/heller-etal 
Hilbig, Romy. (2019). Internationale Geschäftsmodelle von Berufsbildungsdienstleistern: Geschäftsmodellinnovationen unter Berücksichtigung der Dynamic Capabilities. Wiesbaden, Alemania: Springer Gabler.

Instituto Nacional de Estadística y Censo (INEC). (2020a). Encuesta Continua de Empleo al segundo trimestre de 2020: Resultados generales (vol. 1). San José, Costa Rica: INEC.

Instituto Nacional de Estadística y Censo. (2020b). Encuesta Continua de Empleo (ECE): Principales indicadores del mercado laboral costarricense de la población joven y adulta, III Trimestre 2010 - II Trimestre 2020. San José, Costa Rica: INEC.

International Labour Organisation (ILO). (2004). R195 - Recomendación sobre el desarrollo de los recursos humanos, 2004. Conferencia General de la Organización Internacional del Trabajo. Recuperado de https://www.ilo.org/dyn/normlex/es/f?p=NORMLEXPUB:12100:0::NO::P12100 ILO C ODE:R195

Langthaler, Margarita. (2015). The transfer of the Austrian dual system of vocational education to transition and developing countries: An analysis from a developmental perspective. Recuperado de http://hdl.handle.net/10419/113285

Láscarez, Daniel. (2017). Análisis de viabilidad para la implementación de la educación dual: Propuestas de mejoramiento para el sistema de educación técnica en Costa Rica (Tesis de Maestría). Universidad Nacional, Heredia, Costa Rica. Recuperado de http://www.opac.una.ac.cr/F/1R2AUV1I3YV1V5UJTLMT2MR6ES556NGA6896KFHS5 GLNQY8QAK-07751?func=full-setset\&set number $=000480 \&$ set entry $=000003 \&$ format $=002$

Láscarez-Smith, Daniel., \& Baumann, Fabienne-Agnes. (2020): Costa Rica: Berufsbildung im Wandel. In: F.A. Baumann, D. Frommberger, M. Gessler, L. Holle, L. KrichewskyWegener, S. Peters \& J. Vossiek (Eds.), Berufliche Bildung in Lateinamerika und Subsahara-Afrika. Entwicklungsstand und Herausforderungen dualer Strukturansätze. Wiesbaden, Alemania: Springer.

Linten, Markus., \& Prüstel, Sabine. (2019). Internationale Zusammenarbeit und Transfer in der Berufsbildung. Auswahlbibliografie. Bonn, Alemania: BIBB. Recuperado de https://www.bibb.de/dokumente/pdf/stabpwi auswahlbibliografie 201902 internationa le-zusammenarbeit v3.pdf

Mercado, Jader. (2016). Un análisis del concepto de argumento en la teoría de la argumentación de Stephen Toulmin (Tesis). Universidad de Cartagena, Colombia. Recuperado de https://repositorio.unicartagena.edu.co/handle/11227/2825?show=full

Ministerio de Educación Pública [MEP]. (2017). MEP instala comisión tripartita para la Educación Dual. Recuperado de https://www.mep.go.cr/noticias/mep-instala-comisiontripartita-educacion-dual 
Mittmann, Frank. (2001). La educación dual en Costa Rica. proyecto piloto mecánica automática del Colegio Vocacional Monseñor Sanabria 1996-1999. San José, Costa Rica: INA.

Münk, Dieter. (2017). Das Duale System: Funktionslogiken eines nicht exportierbaren Exportschlagers. Berufsbildung: Zeitschrift für Theorie-Praxis-Dialog, 71(165), 3-6.

Peters, Susanne., Gessler, Michael. \& Kühn, Kristina. (2019). Private and public business models in internationalization of VET. In Barbara E. Stalder \& Christof Nägele (Eds.), Trends in Vocational Education and Training Research: Volume II. Proceedings of the European Conference on Educational Research (ECER), Vocational Education and Training Network (VETNET) (pp. 349-357). Recuperado de https://zenodo.org/record/3358906\#.YImoTKFMHIU

Pilz, Matthias. (2016). Typologies in Comparative Vocational Education: Existing Models and a New Approach. Vocations and Learning, 9(3), 295-314.

Prosser, Thomas., \& Perin, Emmanuelle. (2015). European tripartism: chimera or reality? The "new phase" of the European social dialogue in the light of tripartite theory and practice. Business History, 57(3), 376 -397. doi: https://doi.org/10.1080/00076791.2014.983481

Reano, Adriana. (2014). Aproximaciones contemporáneas en torno al lenguaje, a la política y a la ideología. Pensando algunas articulaciones. In E. Torres \& C. del Valle, Discurso y poder Aproximaciones teóricas y prácticas (pp. 33-52). Temuco, Chile: Ediciones Universidad de La Frontera Temuco, Chile.

Romero, Erica., Elgoibar, Patricia., Munduate, Lourdes., García, Ana., \& Euwema, Martin.(2017). Improving social dialogue: What employers expect from employee representatives. The Economic and Labour Relations Review, 29(2), 169-189. doi: https://doi.org/10.1177/1035304617739506

Rützel, Joseph. (1995). Randgruppen in der beruflichen Bildung: Handbuch der Berufsbildung. In R. Arnold \& A. Lipsmeier (Eds.), Handbuch Berufsbildung (pp. 109-120). Opladen, Alemania: $\quad$ Leske + Budrich. Recuperado de https://link.springer.com/content/pdf/10.1007\%2F978-3-322-93636-3.pdf

Stockmann, Reinhard. (2019). Ziele, Wirkungen und Erfolgsfaktoren der deutschen Berufsbildungszusammenarbeit. In M. Gessler, M. Fuchs, \& M. Pilz (Eds.), Internationale Berufsbildungsforschung. Konzepte und Wirkungen des Transfers Dualer Berufsausbildung (pp. 121-162). Wiesbaden, Alemania: Springer VS.

Strahm, Rudolf., Geiger, Bruno., Oertle, Cornelia., \& Swars, Erik (Eds.). (2016). Vocational and professional education and training in Switzerland: Success factors and challenges for sustainable implementation abroad. Bern, Suiza: hep.

Strittmatter, Johannes., \& Böhner, Markus. (2019). Deutsche Berufsbildung in Partnerländern erfolgreich gestalten: Ein praxisorientierter Ansatz für bilaterale Transferprozesse. In M. Gessler, M. Fuchs \& M. Pilz (Eds.), Internationale Berufsbildungsforschung. Konzepte und Wirkungen des Transfers Dualer Berufsausbildung (pp. 515-548). Wiesbaden, Alemania: Springer VS. 
Toulmin Stephen., Rieke, Richard., \& Janik, Allan. (1984). An introduction to reasoning. Nueva York, Estados Unidos: Macmillan.

Toulmin, Stephan. (2007). Los usos de la argumentación. Grupo Editorial 62. Barcelona, España: Ediciones Peninsula.

Toulmin, Stephen. (2003). "The Uses of Argument”. Cambridge, Reino Unido: Cambridge University Press.

van Dijk, Teun (Ed.). (2005). El discurso como interacción en la sociedad. El discurso como interacción social. Estudios sobre el discurso II. Una Introdcción multidisciplinaria. Gedisa Editorial.

Barcelona, España: Gedisa. https://libroschorcha.files.wordpress.com/2017/12/el-discurso-como-interaccic3b3nsocial-teun-van-dijk.pdf

Vilas, Carlos. (2011). Política y políticas públicas en América Latina. Recuperado de http://cmvilas.com.ar/index.php/articulos/12-politicas-publicas/27-politica-y-politicaspublicas-en-america-latina

Wodak, Ruth., \& Meyer, Michael (Eds.). (2003). Métodos del análisis crítico del discurso. Barcelona, España: Gedisa. 


\section{Appendix}

\section{Guía de entrevista semi-estructurada (Spanish original)}

(1) ¿Cuál ha sido su papel en el proceso de diálogo social sobre educación dual? ¿Cómo fue definida su participación por parte del grupo que representa en ese proceso?

(2) El diálogo social es una harramienta política para lograr consensos sobre temas delicados ¿Cómo evalúa el inicio de la mesa de diálogo tripartito para llegar a consensos sobre la educación dual para Costa Rica? ¿Cree que la mesa cuenta con los requisitos mínimos y las reglas claras para lograr los objetivos planteados?

(3) ¿Qué entiende usted por "educación dual" y por qué cree que es importante para Costa Rica?

(4) ¿Cómo fue su experiencia en la visita a Alemania? Cuáles son sus principales aprendizajes?

(5) Los representantes del sector empresarial en la mesa de diálogo y otros fueron invitados a Alemania para conocer más de cerca el modelo dual Alemán para que sirivera de base para las discusiones costarricenses ¿Cómo compara la experiencia entre ambos paises? Cómo pondera el desarrollo del sistema dual en otros paises?

(6) ¿Cuáles son los principales temas de discusión que han desarrollado en la mesa de diálogo tripartito? ¿Cuáles son las propuestas del sector empresarial con respecto a esos temas?

(7) ¿Cómo pondera la representación empresarial la participación sindical con respecto a los temas que se han discutido? ¿Hay puntos de encuentro con las propuestas sindicales? ¿cómo esperan convencer a la representación sindical y estatal de que sus propuestas son las mejores para Costa Rica?

(8) Algunos periodistas han mencionado que el Ministro de Educación ya tiene una postura clara sobre el contrato laboral y sobre los derechos de los aprendices. ¿Cómo evaluan las propuestas y el papel del Gobierno con respecto a esos temas? ¿Cree que hay una postura establecida por parte de los negociadores? ¿Cómo afecta esto a las negociaciones?

(9) ¿Para usted, cómo sería el modelo ideal de educación dual para Costa Rica? ¿El grupo empresarial que usted representa comparte la misma visión? Valore los siguientes aspectos:

- organización

- estructura

- financiamiento

- ente rector

- porcentajes de dualización

- toma de decisiones

- papel de los actores sociales de la EFTP 
(10) Sobre el futuro de la mesa de diálogo y otros proyectos asociados, como el convenio entre el INA, la Cámara de Industria y el Marco Nacional de Cualificaciones ¿Qué espera del futuro del proceso de diálogo? ¿Cuáles son las perspectivas, visiones y proyectos que tienen los diferentes sectores empresariales alrededor de la educación dual?

(11) La educación dual supone una serie de inversiones y costos por parte de las empresas: ¿cómo pretenden obtener beneficios las empresas través de la educacion dual? ¿Cómo es el sistema que garantiza que se puedan obtener beneficios tanto para las empresas como para los estudiantes y la sociedad?

(12) Profundizar en espectos relevantes de la conversación.

\section{Semi-structured interview guide (English translation)}

(1) What has been your role in the social dialogue process on dual education? How was your participation defined by the group you represent in that process?

(2) Social dialogue is a political mechanism to achieve consensus on sensitive issues. How do you evaluate the start of the tripartite dialogue table to reach consensus on dual education for Costa Rica? Do you think that the table has the minimum requirements and clear rules to achieve the objectives set?

(3) What do you understand by "dual education" and why do you think it is important for Costa Rica?

(4) How was your experience during the visit to Germany? What are your main learnings?

(5) The representatives of the business sector at the dialogue table and others were invited to Germany to learn more about the German dual model as a basis for the Costa Rican discussions. How do you evaluate the development of the dual system in other countries?

(6) What are the main topics of discussion that you have developed at the tripartite dialogue table? What are the proposals of the business sector with respect to these topics?

(7) How does employer representation weigh up trade union participation with respect to the issues that have been discussed? Are there any points of contact with the trade union proposals? How do you hope to convince trade unions and state representation that your proposals are the best for Costa Rica?

(8) Some journalists have mentioned that the Minister of Education already has a clear position on the labor contract and on the rights of apprentices. How do you evaluate the proposals and the role of the government with regard to these issues? Do you think that there is a stable position on the part of the negotiators? How does this affect the negotiations?

(9) What would be the ideal model of dual education for Costa Rica from your point of view? Does the business group you represent share the same vision? The following aspects should be included in the vision: 
- organization

- structure:

- financing

- governing body

- degree of dualization

- decision making procedure

- Role of social actors in VET

(10) What do you expect from the future of the dialogue table and other associated projects, such as the agreement between the INA, the Chamber of Industry and the National Qualification Framework? What are the perspectives, visions and projects of the different business sectors around dual education?

(11) Dual education involves a series of investments and costs on the part of companies: how do companies intend to make profits through dual education? What is the system that guarantees that profits can be made for companies, students and society?

(12) Deepen relevant aspects of the conversation. 
Revista indizada en

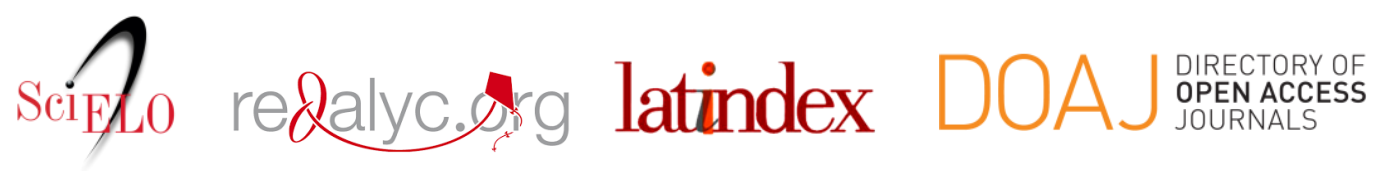

Distribuida en las bases de datos:

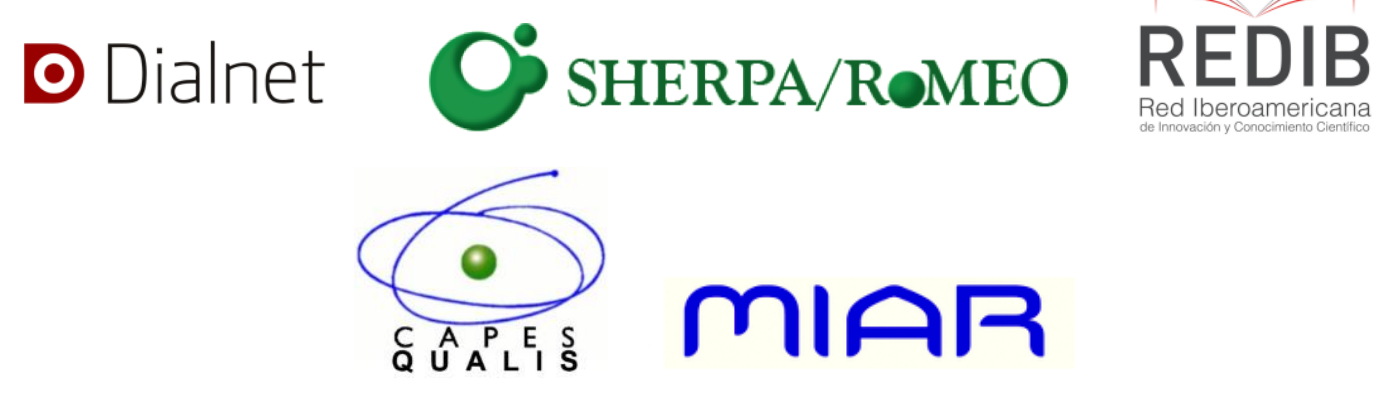

